\title{
Majątek wygrany w karty - jak po powstaniu styczniowym litewskie Kałnoberże znalazły się w rękach rodziny Stołypinów
}

Zarys treści: Majątek ziemski Kałnoberże, położony około 12 kilometrów od Kiejdan w guberni kowieńskiej, był własnością hrabiego Edwarda Czapskiego i został skonfiskowany po powstaniu styczniowym. Od 1869 r. należał do rodziny Stołypinów, a od 1889 r. do Piotra Stołypina, zajmującego wówczas stanowisko уездного предводителья дворянства, czyli marszałka szlachty powiatu kowieńskiego. Według wspomnień Marii Bock, najstarszej córki Piotra Stołypina, majątek ten został wygrany w karty przez jej dziadka, generała Arkadiusza Stołypina. Natomiast polscy ziemianie, sąsiedzi Kałnoberży, twierdzą w swoich wspomnieniach, że ojciec Piotra Stołypina otrzymał go jako nagrodę za udział w stłumieniu powstania na Litwie i późniejszą działalność rusyfikacyjną. Autor, wykorzystując nieznane, odkryte przez siebie materiały archiwalne, potwierdza tezę o wygraniu majątku w karty i szczegółowo przedstawia okoliczności związane z przejęciem Kałnoberży przez generała Arkadiusza Stołypina.

Outline of content: The land estate of Kałnoberże, situated approx. 12 kilometres from Kiejdany in the Kovno Governorate, which belonged to count Edward Czapski, was confiscated from him after the January Uprising. It then became a property of the Stolypin family in 1869, and was passed in 1889 to Pyotr Stolypin who held, at that time, the position of уездный предводитель дворянства, marshal of the nobility of the Kovno County. According to the memoirs of Maria Bock, eldest daughter of Peter Stolypin, her grandfather, General Arkadiy Stolypin had won the estate in a game of cards. However, several Polish landowners from the area claim in their memoirs that Kałnoberże had been given to Pyotr Stolypin's father for his participation in the suppression of the uprising in Lithuania and his later Russification efforts. Yet, based on hitherto unknown archival materials that he recently discovered, the author confirms that the estate was actually won in a bet and presents the circumstances of the take-over of Kałnoberże by General Arkadiy Stolypin.

Słowa kluczowe: Piotr Stołypin, gubernia kowieńska, majątek Kałnoberże, wygrany w karty, nowe materiały archiwalne

Keywords: Peter Stołypin, Kaunas guberniya, estate Kałnoberże, card game, new archival materials 
W Słowniku Geograficznym Królestwa Polskiego i innych krajów słowiańskich z roku 1882 czytamy: „Kałnoberże - dwór i wieś nad rzeką Niewiażą, powiat kowieński, parafia i gmina Surwieliszki o 5 wiorst od Surwieliszek, okręg policyjny i stacja drogi żelaznej Kiejdany (12 wiorst od Kiejdan). Dwór był własnością hr. Edwarda Czapskiego, dziś gen. Stołypina, wieś ma 54 osad włościańskich, kaplica katolicka we wsi drewniana, grunta dobre, łąki obfite"1.

Wszyscy autorzy piszący o Piotrze Stołypinie ${ }^{2}$ powtarzają za jego córką Marią, w jaki sposób generał Arkadiusz Stołypin wszedł w posiadanie majątku Kałnoberże: „mój dziadek otrzymał je za dług karciany. Jego krewny Kuszeliew przegrał do niego w jacht klubie znaczną sumę pieniędzy i powiedział: »W obecnym czasie nie mam wolnych pieniędzy, ale mam niewielką posiadłość na Litwie, gdzieś koło Kiejdan. Sam tam nigdy nie byłem. Chcesz, weź ją sobie za dług “”’. W tym cytacie zastanawiające było, że wnuczka generała Arkadiusza Stołypina nie znała nawet imienia owego Kuszeliewa i stopnia jego pokrewieństwa ze swoją rodziną. Poza tym dziwne wydawało się i to, że oddawał on majątek za nieokreślony dług karciany, w dodatku majątek, którego nigdy nie widzial4.

Całkiem odmienne informacje znajdujemy natomiast $\mathrm{w}$ trzech pamiętnikach napisanych przez trzech polskich ziemian z Kowieńszczyzny, doskonale znających realia społeczne i majątkowe guberni kowieńskiej z II połowy XIX i początku XX wieku. Mieczysław Jałowiecki w interesującym nas okresie był członkiem Komisji Szacunkowej Wileńskiego Banku Ziemskiego i z racji tej funkcji szczegółowo poznał stan majątkowy wielu dóbr ziemskich na Litwie i Białorusi, a jako tzw. taksator banku, czyli osoba, która osobiście wizytowała majątki przed udzieleniem ich właścicielom pożyczki pod zastaw nieruchomości, znał dobrze właścicieli i dzieje wielu posiadłości w sześciu północno-zachodnich guberniach Rosji. Podaje on, że „Stołypin wychował się na Litwie, w okolicach Kiejdan, w majątku Kałnoberże skonfiskowanym po powstaniu hr. Edwardowi Czapskiemu i darowanym jego ojcu"5. Podobnie, w niedrukowanych wspomnieniach dotyczących Kowieńskiego Towarzystwa Rolniczego, pisze Aleksander Meysztowicz, którego majątek leżał

1 Słownik Geograficzny Królestwa Polskiego i innych krajów słowiańskich, t. III, Warszawa 1882, s. 719. W tomie IV tegoż Słownika na s. 274 znajduje się nazwa Kołnoberże z wyjaśnieniem, że jest to inna nazwa Kałnoberży.

2 Wymieńmy tylko kilku: Г. П. Сидоровин, Петр Аркадьевич Столыпин. Жизнь за отечество, Москва 2007, с. 22; А. П. Бородин, Столыпин. Реформы во имя России, Москва 2004, с. 8; Б. Г. Федоров, Петр Стольпин: „Я верю в Россию”. Биография П. А. Стольпина, Т. І, С. Петербург 2002, с. 117; П. Н. Зырянов, Петр Стольпин. Политический портрет, Москва 1992, с. 8; В. Банис, Колноберже, [w:] Петр Аркадьевич Столыпин, Энииклопедия, Москва 2011, с. 242; A. Stołypin, Cesarstwo i wygnanie. Przed i po roku 1917. Pamiętniki. Przy współpracy Dymitra Stołypina, Warszawa 1998, s. 23. Z polskich autorów: L. Bazylow, Ostatnie lata Rosji carskiej. Rządy Stołypina, Warszawa 1972, s. 56, przypis nr 8; J. Nieścioruk, Piotr Stołypin. Życie i działalność polityczna, Lublin 2007, s. 51.

3 М. Бок, П. А. Столыпин. Воспоминания о моем отие, [w:] Российские судьбы. Жизнеописания, факты и гипотезы, портреты и документы в 30 книгах. Издатель К. В. Крепов, Москва 1998, с. 26.

4 To oczywiście nie przeszkadzało w tym, że znał jego wartość, np. z wyceny przy kupnie.

5 M. Jałowiecki, Na skraju Imperium, Warszawa 2000, s. 122. 
w odległości kilkudziesięciu kilometrów od Kałnoberży. Opisując nadanie ojcu Piotra Wierowkina ${ }^{6}$ „połowy dóbr wiżuńskich skonfiskowanych hr. Czapskiemu w 1864 roku”, stwierdza iż: „Podobne nadanie otrzymał ojciec Stołypina”. Kilka stron dalej uzupełnia: „Ojciec Stołypina należał do rusyfikatorów, którzy grasowali po naszym kraju po 1863 r. i otrzymał w nagrodę Kałnoberżę w powiecie kowieńskim należącą do dóbr Kieydańskich"". Informację ojca powtarza w swoich wspomnieniach ksiądz Walerian Meysztowicz, gdy przedstawia swoje pierwsze spotkanie z ówczesnym gubernialnym marszałkiem szlachty kowieńskiej: „Jak się znalazł Piotr Arkadiewicz Stołypin w jadalni w Pojościu. Przyjechał po prostu z niedalekiej Kałnoberży skonfiskowanej Czapskiemu a nadanej jego ojcu - komendantowi carskich pałaców w Moskwie"9.

Relacje te, wprawdzie będące tylko źródłami pośrednimi, zasługiwały na uwagę przede wszystkim z powodu, jak się wydawało, dużej wiarygodności ich autorów. Zwłaszcza Mieczysław Jałowiecki i Aleksander Meysztowicz, jak mało kto znali polski stan posiadania w guberni kowieńskiej. Aleksander Meysztowicz był w latach 1900-1904 wiceprezesem Kowieńskiego Towarzystwa Rolniczego, a od 1908 r. członkiem zarządu Wileńskiego Banku Ziemskiego. W dodatku rozległe kontakty rodzinno-towarzyskie i sąsiedzkie ziemiaństwa kowieńskiego były cennym źródłem informacji o „nowych” posiadaczach ziemskich w guberni, zwłaszcza jeśli obejmowali dobra skonfiskowane prawowitym właścicielom za udział w powstaniu styczniowym. Pojoście należące do Aleksandra Meysztowicza znajdowało się nie tak daleko od Kałnoberży, aby jego właściciele nie wiedzieli, kto otrzymał (nawet nie kupił, gdyż we wszystkich trzech zapisach występuje słowo „nadanie, darowanie”) majątek skonfiskowany dotychczasowemu właścicielowi.

6 Piotr Wierowkin był gubernatorem kowieńskim od 24 kwietnia 1904 r. do 31 grudnia 1912 r.

7 A. Meysztowicz, Kowieńskie Towarzystwo Rolnicze w latach 1900-1904, Zakład Narodowy im. Ossolińskich we Wrocławiu, sygn. 15555, k. 24.

8 Ibidem, k. 27. Dlatego jest błędem stwierdzenie Jarosława Nieścioruka: „Arkadiusz jawił się bardziej jako człowiek, który wniósł wielki wkład w rozwój tych obszarów, a nie jako typowy Wielkorus walczący z polskością" (J. Nieścioruk, Piotr Stołypin. Życie i działalność polityczna, Lublin 2007, s. 19). Autor ten polemizuje z cytowaną powyżej wypowiedzią Aleksandra Meysztowicza dotyczącą generała Arkadiusza Stołypina, nie podając niestety źródeł, na których opiera swoją opinię i polemikę. W przypisie odnosi się tylko (bez podania cytatu) do bardzo lakonicznej wzmianki Konstantego Skirmunta z jego wspomnień. Brzmi ona następująco: „Ojciec jego [Piotra Stołypina R. J.] należał do pierwszej grupy działaczy rosyjskich w naszym kraju po powstaniu 1863. Zdobył wówczas majątek Kolnoberże, część dawnych dóbr kiejdańskich, niegdyś radziwiłłowskich, później Czapskich" (K. Skirmunt, Moje wspomnienia 1866-1945. Wstęp i opracowanie Ewa Orloff, Andrzej Pasternak, Rzeszów 1977, s. 28). Ale nawet bez wiedzy o działalności gen. Arkadiusza Stołypina w Wilnie taki zapis, dokonany przez Konstantego Skirmunta, powinien wzbudzić wątpliwości historyka: Jakich bowiem „działaczy” rosyjskich ściągał Michał Murawiew i Konstanty von Kaufman do Wilna po zdławieniu powstania styczniowego!? I w jaki sposób po tymże powstaniu „działacz rosyjski” mógł „zdobyć” majątek, który należał do Czapskich?

9 W. Meysztowicz, Poszło z dymem, Gawędy o czasach i ludziach, Warszawa 1989, s. 106. Określenie „z niedalekiej Kałnoberży” jest mało precyzyjne. Pojoście leżały 6 kilometrów od Poniewieża, a Kałnoberże były oddalone od Poniewieża o około 73 kilometry. 
W dodatku wspomnienia Mieczysława Jałowieckiego i Aleksandra Meysztowicza były pisane w różnym okresie w różnych częściach Europy (w Rzymie i Londynie), a obaj pamiętnikarze nie mieli żadnych osobistych powodów, aby taką wzmianką celowo oczernić ojca Piotra Stołypina, a tym samym pośrednio jego syna. Poza tym zapisów Aleksandra Meysztowicza nie można też obarczyć błędami i brakami pamięci w latach późnej starości. Dokładnie wiedział o losach Kałnoberży po powstaniu styczniowym, gdy we wspomnieniu pośmiertnym po zabójstwie Piotra Stołypina, opublikowanym w „Kurierze Wileńskim” w 1911 r., napisał: „Ojciec Stołypina, generał wojsk rosyjskich, urzędował w wileńskiej Radzie Miejskiej. Miał własny dom w Wilnie i majątek ziemski Kałnoberżę, Czapskim wraz z Kiejdanami skonfiskowany. Dziwnym zrządzeniem losu w ślad za mordercą [w kijowskim teatrze 1 września 1911 r. - R. J.] jeden z hrabiów Czapskich rzucił się pierwszy..."10. Tutaj nie ma już wprawdzie stwierdzenia, że generał Arkadiusz Stołypin otrzymał ten skonfiskowany majątek (mógł go też kupić), ale skojarzenie jest jednoznaczne.

Cytowany już polski historyk Jarosław Nieścioruk uważa, że ta informacja i wcześniej cytowana opinia Aleksandra Meysztowicza o rusyfikatorskiej działalności generała Arkadiusza Stołypina wynikała „nie tyle z autentycznej wiedzy o rodzinie [Piotra Stołypina - R. J.], ile ze zwykłej niechęci do większości Rosjan, którzy mieli być, zdaniem jego i jemu podobnych, tylko prześladowcami polskości" 11 .

Gdy w 2010 r. przygotowywałem wystąpienie dotyczące Piotra Stołypina na specjalną konferencję poświęconą profesorowi Richardowi Pipesowi z okazji nadania mu tytułu doktora honoris causa Uniwersytetu Warszawskiego ${ }^{12}$, po przeprowadzeniu całej obszernej analizy wymienionych wyżej wspomnień, byłem przekonany, że rację mają polscy pamiętnikarze, nie zaś córka Piotra Stołypina. Napisałem wówczas w podsumowaniu swoich rozważań: „The gambling debt, mentioned by

10 A. Meysztowicz, Wspomnienia i refleksje o Stołypinie, „Kurier Wileński”, 20 IX 1911.

11 J. Nieścioruk, op. cit., s. 19, przypis nr 52. Ta niechęć do Rosjan, według tego autora, miała „Wynikać, jak można przypuszczać, z orientacji politycznej autora tej tezy”. Pogląd ten jest niesprawiedliwy w stosunku do Aleksandra Meysztowicza. Konserwatysta, lojalny obywatel państwa rosyjskiego, uczestnik uroczystości odsłonięcia pomnika Katarzyny II w Wilnie w 1904 r., członek Rady Państwa na pewno potrafił odróżnić Rosjan rusyfikatorów od Rosjan, wprawdzie nielicznych, ale żyjących wśród polskich ziemian, którzy rusyfikatorami nie byli. Co więcej, jako stały rzecznik porozumienia polsko-rosyjskiego, specjalnie szukał u Rosjan pozytywnych odniesień wobec Polaków i zawsze wymieniał takie nieliczne postacie wśród ziemian rosyjskich mieszkających na Ziemiach Zabranych. A orientacja polityczna A. Meysztowicza była w bardzo wielu punktach zbieżna z poglądami Piotra Stołypina. Obaj byli zdeklarowanymi konserwatystami i lojalistami. Posiadali podobne poglądy np. w odniesieniu do zagrożeń rewolucyjnych, siły państwa, kwestii rolnej (serwitutów, komasacji, likwidacji wspólnoty gminnej), polityki zagranicznej wobec Niemiec, rozwoju przemysłu. Dzielił ich, po 1906 r., nacjonalizm wykorzystywany przez Piotra Stołypina do wzmocnienia państwa i skierowany w guberniach zachodnich głównie przeciw Polakom, a w całej Rosji także przeciw np. Finom i Żydom.

12 R. Jurkowski, Tsarist Russia - Bolshevik Russia - contemporary Russia. Special session with the ceremony of conferring the title of doctor honoris causa of the University of Warsaw to profesor Richard Pipes. Warsaw 29-30 June 2010, „Echa Przeszłości” („Echoes of the Past”), R. XII, 2010, p. 211-217. 
M. Bock, was a very convenient and simple way of explaining to the eldest daughter, how he had come into possession of the estate and land which she grew to love so much (and which she later expressed in her memoirs). It is curious, however, that while she provided plenty of details describing other estates in the family including the extended family, she never mentioned the previous owners of the Kałnoberża property (except Kuszeliew)"13.

Tymczasem okazało się, że jednak prawdziwa była wersja zanotowana przez Marię Bock, choć z drobnymi różnicami w szczegółach. W odniesieniu do moich rozważać z 2012 r. było to i jest nadal jakże ważną wskazówką metodologiczną mówiącą, że nawet najbardziej z pozoru wiarygodne źródła pośrednie, zawsze będą tylko źródłami pośrednimi i tylko w ostateczności w oparciu o nie można wysnuwać kategoryczne wnioski.

W 2013 r. podczas poszukiwań w Litewskim Państwowym Archiwum Historycznym w Wilnie znalazłem w zespole Wileńsko-Kowieńskiego Urzędu Ministerstwa Rolnictwa i Dóbr Państwowych ogromną, liczącą ponad tysiąc stron, jednostkę archiwalną dotyczącą majątku Kałnoberże ${ }^{14}$. Wyłaniają się z niej losy Kałnoberży po skonfiskowaniu ich hrabiemu Edwardowi Czapskiemu w 1863 roku. Do sierpnia 1864 r. skonfiskowane dobra znajdowały się w dyspozycji Ministerstwa Dóbr Państwowych. W końcu tego miesiąca do kowieńskiego urzędu Ministerstwa Dóbr Państwowych wpłynął list, wraz z podaniem, datowany na 27 sierpnia 1864 r. i podpisany przez sztabs-rotmistrza Mikołaja Buchmana - oficera sztabowego z I dywizji kawaleryjskiej, pełnomocnika Marii Kuszeliewej, żony generała adiutanta Sergiusza Kuszeliewa, o zgodę na wydzierżawienie od skarbu państwa majątku Kałnoberże ${ }^{15}$. Już 30 sierpnia 1864 r. ówczesny gubernator kowieński, generał major Mikołaj Murawiew (najstarszy syn Michała Murawiewa), powiadomił kowieński urząd Ministerstwa Dóbr Państwowych, że „nie znajduje przeciwwskazań wobec tej prośby"16. Po wielu jeszcze urzędowych listach, zaświadczeniach i zgodach żona generała adiutanta Sergiusza Kuszeliewa została dzierżawcą majątku Kałnoberże. Ale nie trwało to długo. Okazja do zmiany formy własności pojawiła się po 23 lipca 1865 r., gdy, już za rządów generała-gubernatora Konstantego von Kaufmana w Wilnie, cesarz Aleksander II zatwierdził „Instrukcję o sprzedaży gruntów skarbowych oraz majątków skonfiskowanych..." ${ }^{17}$. Generał

13 R. Jurkowski, „I Left Quite a Few Friends There”. Piotr Stolypin and Polish Landowners from the Taken Lands between 1899 and 1911, [in:] Russia: of the Tsars, of the Bolsheviks, of the new times, Edited by Jan Malicki, Centre for East European Studies University of Warsaw, Warsaw 2012, p. 43-44.

14 Lietuvos Valstybės Istorijos Archyvas, Vilnius [dalej: LVIA], Ф. 525 (Управление Земледелия и Государственных Имуществ в Виленской и Ковенской губерни), оп. 18, д. 102 (Дело о передаче в казну конфискованного у графа Чапского имения Калноберже, Ковенского уезда и о передаче его в аренду. Имеется инвентарное описание имения 1863 г., л. 1-1240).

15 Ibidem, л. 90.

16 Ibidem, л. 91.

17 Полное Собрание Законов Российской Империи, Собрание второе, Т. XL, 1865, № 41 957; T. XLII, № 42328 a. Właściciele majątków nabytych na podstawie instrukcji, stąd nazwa - majątki instrukcyjne, nie mieli prawa sprzedawania, odstępowania, darowania lub zapisania ich $\mathrm{w}$ testamencie 
lejtnant Sergiusz Kuszeliew ${ }^{18}$, jak pisze Borys Fiedorow, „, z powodu skrajnie niskiej ceny"19, zwrócił się latem 1867 r. do Ministerstwa Dóbr Państwowych z prośbą o zgodę na zakup, na zasadach instrukcji z 23 lipca 1865 r., majątku dotychczas dzierżawionego przez jego żonę. Zgodnie z literą instrukcji z 23 lipca 1865 r. każda sprzedaż majątku na tzw. instrukcyjnego powinna być zatwierdzona przez cesarza i Aleksander II w dniu 18 października 1867 r. wyraził zgodę na zakup Kałnoberży przez generała Sergiusza Kuszeliewa. Zarządzający dobrami państwowymi w guberni kowieńskiej został o tym powiadomiony przez Aleksandra Zielenoja - ministra dóbr państwowych listem z 25 października 1867 roku $^{20}$. Określono w nim warunki sprzedaży. Majątek o powierzchni 941,49 dziesięcin sprzedano generałowi adiutantowi za 23036 rubli i 71 kopiejek na następujących warunkach: „przy podpisaniu aktu kupna generał powinien wnieść piątą część tej sumy (dokładnie 4607 rubli, 34 kopiejki), a pozostałe cztery piąte uiścić w przeciągu 37 lat poprzez coroczne raty wynoszące $6 \%$ od wysokości długu pozostałego do spłacenia"21. Dodatkowo, w związku z tym, iż w 1868 r. nadal jeszcze nie była zakończona sprawa długów spoczywających na majątkach hr. Edwarda Czapskiego, minister Aleksander Zielenoj polecał, aby suma 4 607,34 rubli, jak i sumy wykupne płacone przez włościan z ziemię nadziałową po reformie z 1861 r., były gromadzone na specjalnym koncie kredytowym do czasu obliczenia długów hrabiego Edwarda Czapskiego spoczywających na tym majątku. W akcie zakupu majątku $\mathrm{z}$ dnia 6 marca 1868 r. określono także dodatkowe zasady dotyczące długów ciążących na majątku. W oparciu o ukaz z 5 marca 1864 r. i prawa z 23 października 1864 r. długi te powinny być pokryte z sumy, którą gen. Sergiusz Kuszeliew zapłacił za majątek, „a gdyby i tego było za mało to z rachunków sum wykupnych za uwłaszczoną ziemię [...] część pozostała powinna być oddana do skarbu”22.

Ale między 6 marca a końcem maja 1868 r. generał Sergiusz Kuszeliew przegrał w karty na rzecz gen. Arkadiusza Stołypina dużą sumę pieniędzy, za którą oddał

Polakom. Wejście w posiadanie majątku było każdorazowo warunkowane zgodą cesarza, po uprzednim zaopiniowaniu przez generała-gubernatora i ministra dóbr państwowych. Instrukcja obejmowała tylko urzędników państwowych, a więc i wojskowych, którzy przybyli do guberni zachodnich po 1863 r. Ceny tych majątków były bardzo niskie. Początkowo ich wartość szacowano przez obliczenie rocznego dochodu plus $10 \%$. Po kilku latach ceny sprzedaży podniesiono, lecz spłaty rozkładano na 20, 30 lub więcej lat i nie były one oprocentowane.

18 Generał infanterii (piechoty) Sergiusz Kuszeliew (1821-18 września 1890 r.) był synem generała Jegora Kuszeliewa (1763-1826). Syn Piotra Stołypina - Arkadiusz - popełnia błąd w swoich wspomnieniach (op. cit., s. 23), pisząc o „admirale Kuszeliewie”, myląc generała Sergiusza Kuszeliewa, kupca majątku Kałnoberże, z admirałem Grigorijem Kuszeliewem (1754-1833). Prawdopodobnie za Arkadiuszem Stołypinem błąd ten powtarza Walery Czerepica (В. Н. Черепица, П. А. Стольпин (1862-1911)- гродненский губернатор и великий реформатор России, [w:] История Гродненщины ХІХ столетия в событиях и лицах (исследования, документы, комментари), Гродно 2003, с. 41).

19 Б. Г. Федоров, Петр Стольпин: „Я верю в Россию”. Биография П. А. Стольпина, T. I. С. Петербург 2002, с. 117.

20 LVIA, Ф. 525, оп. 18, д. 102, л. 463.

21 Ibidem.

22 Ibidem, л. 474. 
niedawno nabyty majątek. Suma ta była mniejsza niż wartość majątku, ale wystarczająco duża, aby Sergiusz Kuszeliew nie był w stanie uregulować jej gotówką. Już w maju 1868 r. zwrócił się do ministra Aleksandra Zielenoja z prośbą o zgodę na sprzedaż tego majątku generałowi Arkadiuszowi Stołypinowi. Informuje o tym list ministra A. Zielenoja do zarządzającego dobrami państwowymi w guberni kowieńskiej z 12 lipca 1868 roku $^{23}$. Dowiadujemy się z niego, że generał Sergiusz Kuszeliew „Zwrócił się z prośbą o zgodę na sprzedaż tego majątku za dług, krewnemu swojemu gen. Arkadiuszowi Stołypinowi”24 . Minister zasięgnął opinii generała-gubernatora wileńskiego Aleksandra Potapowa, który będąc w okresie od 14 lipca 1864 r. do 17 kwietnia 1865 r. zastępcą Michała Murawiewa do spraw cywilnych, doskonale znał generała Arkadiusza Stołypina, a nawet, jak wskazują inne dane, przyjaźnił się z nim ${ }^{25}$. Opinia była oczywiście pozytywna i ojciec przyszłego premiera Rosji uzyskał prawo do nabycia majątku Kałnoberże, na zasadach określonych w instrukcji z 23 lipca 1865 roku. Ale nie stało się to szybko. Okazało się bowiem, że wielkość majątku (941,49 dz.), który kupił generał Sergiusz Kuszeliew, nie zgadza się ze stanem rzeczywistym i nieprawidłowość tę wykrył generał Arkadiusz Stołypin, potencjalny nowy właściciel Kałnoberży. Po dokonaniu lustracji majątku generał Arkadiusz Stołypin porównał jego plany ze stanem faktycznym, w wyniku czego zauważył, że w rzeczywistości jest on mniejszy niż powierzchnia, za którą zapłacił gen. Sergiusz Kuszeliew. W obrębie majątku Kałnoberże znalazły się ziemie chłopskie, nadzielone po reformie 1861 r., których nie wyodrębniono przed sprzedażą i za które gen. Sergiusz Kuszeliew zapłacił, jakby należały do posiadłości. Nowy nabywca natychmiast poinformował o tym gubernatora kowieńskiego Michała Oboleńskiego, który listem datowanym na 21 września 1868 r. prosił naczelnika kowieńskiego urzędu Ministerstwa Dóbr Państwowych o „dokonanie korekty obszaru majątku i zmniejszenia opłaty za jego wykup" 26 . Generał Arkadiusz Stołypin kierował się nie tylko opiniami zarządcy majątku, ale sięgnął też do obliczeń dotyczących wielkości majątku dokonanych przez specjalną tzw. Komisję Sprawdzającą, która po wydaniu Instrukcji z 23 lipca 1865 r., ponownie, zgodnie z wytycznymi tej instrukcji, oszacowała powierzchnię i wartość całego majątku. Według planów dołączonych do raportu tej komisji z 29 sierpnia 1865 r. na działki dla uwłaszczonych chłopów zabrano z majątku Kałnoberże 165,21 dz. ziemi, ale jednocześnie z działek chłopskich „odcięto” 108, 21 dz., co oznaczało, że majątek stracił 57 dziesięcin ziemi. Jak wynika z raportu Komisji Sprawdzającej, te 57 dziesięcin „młodego lasu rozdzielone zostało pomiędzy chłopów w zamian za ich zgodę na likwidację serwitutu

23 Ibidem, л. 528.

24 Ibidem.

25 Przyjaźń lub bardo dobrą znajomość obu generałów potwierdza list Arkadiusza Stołypina dołączony do jego memoriału o kwestii żydowskiej, skierowanego do Aleksandra Potapowa w październiku 1873 r. List zaczyna się od słów: „Kochany przyjacielu Aleksandrze Lwowiczu...” (LVIA, Ф. 378 (Канцелярия виленского, ковенского и гродненского генерал-губернатора), оп. 216, д. 397, л. 1).

26 LVIA, Ф. 525, оп. 18, д. 102, л. 537. 
opałowego (leśnego) - licząc po jednej dziesięcinie lasu na chatę"27. Wydawać by się mogło, że obliczenia komisji przedstawiają ostateczny kształt majątku, ale tak nie było, gdyż tych 57 dziesięcin nie odliczono od obszaru, za który zapłacił gen. Sergiusz Kuszeliew. W dodatku ziemie odcięte od gospodarstw chłopskich „były kawałkami nic niewartymi”, podczas gdy ziemia uwłaszczona była dobrej jakości. Arkadiusz Stołypin, mając pełne poparcie Sergiusza Kuszeliewa, w liście do gubernatora kowieńskiego z 21 września 1868 r. proponował dwa sposoby rozwiązania tego problemu, pozostawiając władzom decyzję, który sposób wybrać: 1 . Unieważnienie raportu Komisji Sprawdzającej i pozostawienie majątku w stanie, w jakim kupił go gen. Sergiusz Kuszeliew; 2. Natychmiastowe powołanie nowej komisji szacunkowej, która określiłaby rzeczywistą powierzchnię majątku i oceniła straty, które on poniósł w okresie od objęcia dzierżawy przez Marię Kuszeliew do chwili ponownego uregulowania spraw własnościowych. Przyjęcie pierwszej propozycji oznaczało dla kowieńskiego urzędu Ministerstwa Dóbr Państwowych konieczność zwrotu kosztów dzierżawy tych 57 dziesięcin, zwrotu różnicy w cenie za ziemie uwłaszczone i ziemie „odcięte” od gospodarstw chłopskich i przyłączone do majątku oraz zwrotu wartości urządzeń i zabudowań rolniczych, które przeszły do chłopów wraz 57 dziesięcinami ziemi, a za które zapłacił gen. Sergiusz Kuszeliew. W każdym przypadku należało albo oddać pieniądze, albo zmniejszać cenę majątku, obniżając wysokość kolejnych rat. Poza tym to rozwiązanie nie zabezpieczało Ministerstwa Dóbr Państwowych przed ewentualnymi dalszymi roszczeniami nabywców. Drugi sposób miał jedną podstawową zaletę - definitywnie rozstrzygałby kwestie własności ziemi między chłopami a właścicielem Kałnoberży i byłby podstawą do skorygowania, lub nie, umowy dotyczącej kupna majątku. Cała sprawa, wraz z opisem, powędrowała do Petersburga, gdyż kowieński urząd Ministerstwa Dóbr Państwowych nie podlegał gubernatorowi kowieńskiemu, a ministerstwu kierowanemu przez Aleksandra Zielenoja. Ministerstwo Dóbr Państwowych zaakceptowało drugi sposób i poleciło naczelnikowi Kowieńskiej Komisji Lustracyjnej ponownie oszacować wartość majątku i dokonać pomiarów jego rzeczywistej powierzchni. Wyniki pracy tej komisji były zaskakujące dla wszystkich. W sprawozdaniu datowanym na 24 listopada 1868 r. naczelnik Kowieńskiej Komisji Lustracyjnej poinformował naczelnika kowieńskiego urzędu Ministerstwa Dóbr Państwowych, że na mocy aktów wykupnych chłopi otrzymali $234,97 \mathrm{dz}$. ziemi należącej do majątku, a od ich gruntów „odcięto” na korzyść Kałnoberży 120,65 dz. ziemi, czyli że majątek stracił aż 114,32 dziesięcin, a jego wartość obliczono na 17 303,66 rubli² ${ }^{28}$. Taka ocena wywołała widoczną irytację ministra Aleksandra Zielenoja, który w obszernym liście do naczelnika kowieńskiego urzędu Ministerstwa Dóbr Państwowych, datowanym na 11 stycznia 1869 r. szczegółowo opisał zaistniałą sytuację i polecił dokonanie korekty obszaru majątku wraz ze znalezieniem i ukaraniem winnych

27 Ibidem, k. 576.

28 Ibidem, л. 49-552 (Рапорт Ковенской Люстрационной Коммиссии, Начальнику Ковенского Отделения Министерства Государственных Имуществ, 24 ноября 1868 года). 
takiego stanu rzeczy ${ }^{29}$. Tych ostatnich nie znaleziono, choć wiadomo było, że błędy wynikały z tego, iż Komisja Sprawdzająca w 1865 r. nie dokonała szczegółowego przejrzenia aktów wykupnych spisanych z włościanami po reformie 1861 roku. W następstwie jeszcze wielu ocen, pomiarów i obszernej korespondencji w czerwcu 1869 r. ostatecznie określono obszar i wartość majątku Kałnoberże. Mówi o tym list ministra Aleksandra Zielenoja do naczelnika kowieńskiego urzędu Ministerstwa Dóbr Państwowych, datowany na 23 czerwca 1869 r.: „Kałnoberże, po zmianach liczą 836,25 dz. ziemi, z tego zajętej pod dom i zabudowania folwarczne - 11,32 dz.; ziemia uprawna - 298,41 dz.; łąki - 196,34 dz.; las - 203,74 dz.; pastwiska - 100,69 dz. i nieużytki $25,45 \mathrm{dz}$., co oznacza mniej o 105,14 dziesięcin niż uprzednio" ${ }^{30}$. Jednocześnie minister informował, że wartość majątku zmniejszyła się do kwoty 15 831,97 rubli, czyli o 7 204,67 rubli. Jak wynika z listu ministra, generał Sergiusz Kuszeliew nie negował prawidłowości tej oceny, ale wnioskował o podniesienie kwoty obniżki o 20\%, czyli o dodatkowe 1440 rubli. Ministerstwo z kolei zgadzało się na zwiększenie kwoty bonifikaty o 10\%. Decyzja ostateczna należała do Aleksandra II, który po zapoznaniu się z informacjami ministra zaakceptował zwiększenie sumy obniżki o 15\%, co oznaczało, iż ostatecznie majątek Kałnoberże wyceniono na 14 751,27 rubli. Zatwierdzenie przez monarchę tej wyceny i warunków ponownej sprzedaży nosi datę dziewiątego czerwca 1869 roku.

Cała sprawa szła gładko i szybko, cesarz lekką ręką obniżył wycenę o 720 rubli i nie tylko dlatego, że majątek kupował generał $\mathrm{z}$ armii rosyjskiej - przecież podobnych jemu generałów było w tej armii bardzo wielu. Aleksander II dawał to, co właściwie nigdy nie należało do państwa rosyjskiego, a było przemocą zabrane prawowitemu właścicielowi za to, że w walce o wolność dla Rzeczypospolitej odważył się podnieść rękę na Imperium Romanowów.

W dniu 18 sierpnia 1869 r. Ministerstwo Dóbr Państwowych oraz generał Sergiusz Kuszeliew zawarli nową umowę kupna-sprzedaży majątku Kałnoberże ${ }^{31}$. Zawierała ona następujące zapisy: 1. Unieważniała umowę z 6 marca 1868 r.; 2. Anulowano i przeniesiono na drugą umowę wszystkie opłaty sądowe związane $\mathrm{z}$ zawarciem umowy, a różnicę oddano gen. Sergiuszowi Kuszeliewowi, „aby mógł tę nadwyżkę oddać swojemu dzierżawcy"; 3. Umowa dotyczyła majątku o powierzchni 836,25 dz. o wartości 14 751,27 rubli. 4. Pierwsza wpłata wynosiła 2950,21 rubli (czyli ${ }^{1 / 5}$ wartości) - pobrano ją z kwoty 4611,35 rubli, którą wpłacił przy pierwszej umowie. Pozostałość zaliczono na poczet rat, które powinien zgodnie z umową spłacić w ciągu 37 lat. Generał Sergiusz Kuszeliew był właścicielem Kałnoberży przez całe

29 Ibidem, л. 574-579.

$30 \mathrm{Ibidem}$, л. 652-658. W tym miejscu warto zwrócić uwagę, że wyliczenia podane w liście ministra zawierały drobne błędy rachunkowe. Zsumowanie powierzchni pod poszczególnymi rodzajami upraw dawało $835,95 \mathrm{dz}$., a nie podaną wielkość $836,25 \mathrm{dz}$. Podobnie było z liczbą przedstawiającą stratę ziemi w majątku. Odjęcie wartości 836,25 dz. od 941,49 dz. dawało 105,24 dz., a nie jak podano 105,14 dz.

31 Ibidem, л. 751. (Письмо Временного отдела по поземельному устройству государственных крестьян, Министерства Государственных Имуществ, начальнику Ковенского Отделения Министерства Государственных Имуществ, 14 апреля 1870 г.). 
10 dni - 28 sierpnia 1869 r. sprzedał majątek generałowi Arkadiuszowi Stołypinowi, który „pragnąc jednorazowo zlikwidować wszystkie pozostałe obciążenia” - wpłacił do kowieńskiego gubernialnego urzędu skarbowego, w dniu 16 grudnia 1869 r., sumę 10300 rubli $^{32}$. Na tę sumę składała się cena majątku (10 143 ruble), resztę stanowiła należność za wszystkie budowle znajdujące się na ziemiach oddanych włościanom, które przejmował nowy właściciel.

Proste odjęcie kosztu majątku od sumy, którą generał Arkadiusz Stołypin wpłacił do skarbu państwa, przynosi informację o wysokości długu karcianego Sergiusza Kuszeliewa, o którym pisała Maria Bock. Można przyjąć, iż wynosił on około 5000 rubli. Nie jest zatem w pełni ścisłe stwierdzenie najstarszej córki Piotra Stołypina, że jej dziadek „wygrał majątek w karty”, gdyż wygrał tylko jedną trzecią majątku, licząc według drugiej, znacznie niższej wyceny. W przypadku pierwszej wyceny było to mniej niż $1 / 4$ wartości. Poza tym nie jest też prawdziwa ta część wypowiedzi Marii Bock, w której cytuje ona słowa generała o tym, iż Sergiusz Kuszeliew nigdy nie był w Kałnoberżach. Dokumenty i listy pisane przez obu generałów w sprawie majątku do odpowiednich urzędów świadczą, że doskonale znali jego sytuację gospodarczą, stan zabudowań i rozplanowanie różnych kategorii upraw.

Wartą odnotowania jest wyraźnie zauważalna w dokumentacji pełna zgodność obu generałów w dążeniu do maksymalnego zmniejszenia ceny majątku Kałnoberże. Było to oczywiście w interesie ich obydwu, lecz rola wiodąca przypada tu, jako właścicielowi, generałowi Sergiuszowi Kuszeliewowi. Skrzętnie wykorzystał on dwie okazje: fakt, iż od 30 sierpnia 1864 r. do 6 marca 1868 r. jego żona była dzierżawcą Kałnoberży i błędy w ocenie powierzchni majątku. Gdy w lipcu 1868 r. generał-gubernator wileński, grodzieński i kowieński wyraził zgodę na sprzedaż majątku gen. Arkadiuszowi Stołypinowi - już w dniu 30 października tegoż roku Czasowy Oddział Ministerstwa Dóbr Państwowych do Spraw Urządzenia Chłopów Państwowych otrzymał od naczelnika kowieńskiego urzędu Ministerstwa Dóbr Państwowych informację, że „pełnomocnik Marii Kuszeliewej, sekretarz gubernialny Bachmiarow zwrócił się do ministerstwa z podaniem o zwrot ze skarbu państwa 899 rubli, które wydała Maria Kuszeliewa na niektóre modernizacje budynków i urządzeń w Kałnoberżach" ${ }^{33}$. Była to niemała suma, jak na niecałe 4 lata dzierżawy. Wzbudziło to wątpliwości urzędników w ministerstwie zapewne zdziwionych nie tylko znacznymi inwestycjami, które poczynił dzierżawca, ale jeszcze bardziej tym, że w ogóle był taki dzierżawca, który podejmował się jakichkolwiek inwestycji w majątku niebędącym jego własnością. $\mathrm{O}$ tym, że sumy te były wzięte z powietrza, urzędnicy ministerstwa upewnili się po ocenie dochodowości majątku dokonanej w listopadzie 1868 r. przez Kowieńską Komisję Lustracyjną. Roczny dochód z Kałnoberży (o powierzchni $836,25 \mathrm{dz}$.) wyliczono na 996,15 rubli i to przy uwzględnieniu sprzedaży części lasu za 278,37 rubli, a było wszystkim wiadome, że lasu,

32 Ibidem.

33 Ibidem, л. 580. 
którego w majątku było nieco ponad $200 \mathrm{dz}$., nie sprzedaje się co roku ${ }^{34}$. Ale generał Sergiusz Kuszeliew był zbyt znaną postacią, aby zbagatelizować podanie jego żony, dlatego naczelnik Czasowego Oddziału Ministerstwa Dóbr Państwowych do Spraw Urządzenia Chłopów Państwowych polecił podwładnym w Kownie „sprawdzić wymienione modernizacje i wycenić wszystkie zmiany"35. Podobnie jak żona, o inwestycjach w nabyty majątek pisał także generał Sergiusz Kuszeliew w liście domagającym się zwiększenia o $20 \%$ obniżki ceny całej posiadłości. Do swoich kosztów, obok inwestycji w nieruchomości, dodawał też: „ponowne sporządzenia aktu kupna, konieczność oddania dzierżawcy sum pobranych od niego za ziemię chłopską itp." ${ }^{36}$. I jeśli powyższe przykłady świadczyły o tym, że nie zaniedbał on żadnej okazji, aby wyciągnąć od skarbu państwa większe lub mniejsze sumy pieniędzy, to były także zdarzenia, które można nazwać już tylko zwykłym odzyskiwaniem swojej własności. W dniu 30 listopada 1868 r., a więc w niecały tydzień po sporządzeniu raportu o błędnych obliczeniach powierzchni Kałnoberży przez Kowieńską Komisję Lustracyjną (24 listopada 1868 r.), Czasowy Oddział Ministerstwa Dóbr Państwowych do Spraw Urządzenia Chłopów Państwowych polecił naczelnikowi kowieńskiego urzędu Ministerstwa Dóbr Państwowych, aby wypłacił generałowi Sergiuszowi Kuszeliewowi sumę 91,02 rubla jako zwrot podatku, który tenże zapłacił (w okresie 11-23 kwietnia 1868 r.) za ziemie należące do włościan, a błędnie przypisane do posiadłości Kałnoberże ${ }^{37}$. Także generał Arkadiusz Stołypin jeden raz wziął udział w próbie zarobienia więcej, niż zezwalały na to istniejące przepisy. W liście, prawdopodobnie z sierpnia 1868 r., do gubernatora kowieńskiego wymienił on straty, które poniósł majątek na skutek wadliwego obliczenia jego powierzchni i oddania włościanom niektórych trwałych obiektów gospodarczych należących do Kałnoberży. O tym, że te wyceny były zawyżone, pisał naczelnik Kowieńskiej Komisji Lustracyjnej w raporcie z 24 listopada 1868 r.: „wyceny dokonałem nie według strat podanych przez gen. Stołypina, a według przepisów określonych w instrukcji z 23 lipca 1865 r. i ukazie z 6 marca 1866 r." ${ }^{38}$. Dodam zaraz, że przepisy te znacznie zaniżały wyceny majątku ruchomego i nieruchomego skonfiskowanego za udział w powstaniu, wszak niskie ceny miały zachęcić nowych nabywców „rosyjskiej narodowości i prawosławnego wyznania” do kupowania tych posiadłości.

Można zadać pytanie, czy kwota 10143 rubli i 93 kopiejek (bo nie uwzględniam długu karcianego, tylko sumę realnie wpłaconą za majątek przez gen. Arkadiusza Stołypina) za 836,25 dziesięciny ziemi była wysoka czy nie? Jeśli wziąć pod uwagę średnie ceny ziemi ornej w Rosji Europejskiej w okresie 1868-1877 wynoszące 19,1 rubla za dziesięcinę (co pomnożone przez $298,41 \mathrm{dz}$. dawało 5700 rubli) i dodać do tego wartość dwóch folwarków z zabudowaniami, inwentarzem i dwór w Kał-

34 Ibidem, л. 660-664. (Обяснительная записка по образовании участка для продажи лицам Русского происхождения из конфискованного имения Колнобержи).

35 Ibidem, л. 580

36 Ibidem, л. 653.

37 Ibidem, л. 559.

38 Ibidem, л. 550. 
noberżach, to suma ta była bardzo mała, zwłaszcza że jej spłata była rozłożona na 37 lat. To, że generał Arkadiusz Stołypin spłacił ją jednorazowo, zależało tylko od jego decyzji, którą należy uznać za niezbyt przemyślaną, zwłaszcza że raty rozłożone na wiele lat były ratami bezprocentowymi. I nawet jeśli uwzględnić fakt, że w tym okresie wystąpił znaczący spadek cen ziemi w guberniach zachodnich, spowodowany ogromną podażą ziemi ze skonfiskowanych majątków polskich (średnio w 5 guberniach tzw. Kraju Północno-Zachodniego, bez guberni kowieńskiej w latach 60. XIX wieku dziesięcina ziemi kosztowała 11,45 rubla) ${ }^{39}$, to nadal byłaby to suma mała. Jak widać z wyceny Komisji Lustracyjnej, wartość budynków, zabudowań gospodarczych i innych obiektów należących do Kałnoberży i folwarku Łamikiszki przekraczała wartość całej ziemi ornej ${ }^{40}$. Nie należy też zapominać, że ceny ziemi zaczęły już rosnąć w połowie lat 70., aby mimo kryzysu lat 80. dojść w powiecie kowieńskim w roku 1886 do średniej 78,81 rubla za dziesięcinę $e^{41}$. Stały wzrost cen ziemi powodował, że Kałnoberże przez cały czas zyskiwały na wartości.

Rosyjski historyk Borys Fiedorow wspomina o „legendzie” mówiącej, iż „Arkadiusz Dmitrjewicz otrzymał bezpłatnie skonfiskowany majątek, ale potem dobrowolnie, z wdzięcznością zwrócił jego wartość poprzednim właścicielom”, ale niestety nie podaje źródła tej legendy ${ }^{42}$. Z cytowanych wyżej dokumentów znajdujących się w Litewskim Państwowym Archiwum Historycznym w Wilnie jednoznacznie widać, że generał Arkadiusz Stołypin część tego majątku wygrał w karty, a za resztę zapłacił. O dalszym postępowaniu generała wobec byłego właściciela, czyli o wspomnianej „legendzie”, nigdzie nie udało mi się znaleźć jakiejkolwiek informacji ${ }^{43}$. Prawowity

39 В. П. Панютич, Социально-экономическое развитие белоруской деревни в 1861-1900 г2., Минск 1990, с. 118.

40 LVIA, Ф. 525 (Управление Земледелия и Государственньх Имуществ в Виленской и Ковенской губерни), оп. 18, д. 102 (Дело о передаче в казну конфискованного у граба Чапского имения Калноберже, Ковенского уезда и о передаче его в аренду. Имеется инвентарное описание имения 1863 г., л. 742 (Описание и оценка строений конфискованного имения Колноберже).

$41 \mathrm{~W} 1886 \mathrm{r}$. ceny ziemi w innych powiatach guberni kowieńskiej wyglądały następująco: poniewieski - 92,2 rubla za dziesięcinę, wiłkomirski - 78,32 rubla, szawelski - 70,61, nowoaleksandrowski (jezioroski) - 66,34, rosieński - 55,5, telszewski - 52,66 rubla za dziesięcinę (И. М. Липинский, Некоторье данные для изучения ковенской губерни в статистическом отношении, [w:] Памятная книжка ковенской губернии на 1889 год, Ковна 1888, с. 322). W tym samym czasie średnie ceny ziemi w guberniach Rosji Europejskiej sprzedawanej przez Bank Włościański były znacznie niższe. W latach 1882-1885 było to 52 ruble za dziesięcinę; 1886-1890: 39 rubli; 1891-1895: 40 rubli; 1896-1900: 71 rubli. (Энциклопедический словарь Ф. А. Брокгауза и И. А. Ефрона, Т. II (4), С. Петербург 1891, c. 926-930). Wysokie ceny ziemi w guberniach zachodnich, po okresie konfiskat, miały swe źródło przede wszystkim w jej bardzo niskiej podaży spowodowanej oporem polskich ziemian przeciw tzw. ukazom grudniowym (10 grudnia 1865 r. i 27 grudnia 1884 r.), które zezwalały katolikom na sprzedaż ziemi tylko osobom wyznania prawosławnego lub innego niekatolickiego. (Szerzej o tym: R. Jurkowski, Ziemiaństwo polskie Kresów Pótnocno-Wschodnich 1864-1904, Działalność społeczno-gospodarcza, Warszawa 2001, s. 106-113).

42 Б. Г. Федоров, ор. cit., Т. I, с. 117.

43 Co ciekawe, w niektórych biografiach generała Edwarda Totlebena podaje się, że majątek Kiejdany (obok miasteczka o tej nazwie), należący do hr. Mariana Czapskiego i skonfiskowany po powstaniu styczniowym, generał Edward Totleben „otrzymał od Aleksandra II za zasługi wojenne”, 
właściciel Kałnoberży, hr. Edward Czapski, po 1871 r. wrócił z zesłania i za zgodą władz rosyjskich osiadł w majątku Swojatycze ( 24 km od Nieświeża). Podjął wówczas starania o odzyskanie od państwa rosyjskiego włościańskich sum wykupnych za jego posiadłości uwłaszczone po reformie 1861 roku. Uwłaszczenie miało miejsce na kilka lat przed powstaniem i mimo konfiskaty Kałnoberży, w świetle prawa, pieniądze te należały się ówczesnemu właścicielowi. Tak też orzekła Wileńska Izba Karna w wyroku z 27 września 1874 r., o czym hr. Edward Czapski poinformował kowieński urząd Ministerstwa Dóbr Państwowych w liście z 5 listopada 1874 $\mathrm{roku}^{44}$. W liście tym wymienia kwoty sum wykupnych i zdanie kończy słowami: „za oddane jako włościańskie nadziały ziemie mojego majątku Kałnoberże”. Nad słowem "mojego" znajduje się dopisek „byłego”, a dodatkowo na drugiej, czystej stronie listu znajdujemy taką własnoręczną uwagę, wraz z podpisem hr. Edwarda Czapskiego: „Zaznaczam, że na pierwszej stronie w 17 linijce dopisałem słowo "byłego «" 45 . Prawowity właściciel, korespondując z władzą, która zabrała mu jego własność, tłumaczył się tej władzy z tego, że, wspominając o swojej własności, od razu nie napisał o „byłym” swoim majątku! ${ }^{46}$

Kałnoberże nie były jedyną posiadłością, którą nabył generał Arkadiusz Stołypin w guberni kowieńskiej. Drugą były Ignacegrody, skonfiskowane Jakubowi Gieysztorowi w 1863 r. za udział w powstaniu ${ }^{47}$. Generał Arkadiusz Stołypin kupił majątek Ignacegrody po dwóch licytacjach przeprowadzonych 22 i 28 stycznia 1874 r. przez Wileński Urząd Gubernialny. W drugiej licytacji generał zapłacił 24100 rubli za „skonfiskowany u politycznego przestępcy Jakuba Gieysztora majątek Ignacegorody z folwarkiem Ejgule, zaściankiem Rekieng, z młynem wodnym i sadami owocowymi przy majątku" 48 . Majątek i folwark liczyły, według podanego w dokumencie podsumowania, łącznie 489 dziesięcin i 1848 sążni kwadratowych [ 1 sążeń $^{2}=4,5522$ $\mathrm{m}^{2}$ ]. Decyzję o nabyciu przez generała Arkadiusza Stołypina pełnych praw własności do majątku Ignacegrody Kowieńska Izba Sądu Karnego i Cywilnego podjęła

a w innych, że kupił go w 1866 r. Jest też wersja podobna jak u Borysa Fiedorowa dotycząca Kałnoberży, że E. Totleben dostał skonfiskowany majątek, ale z własnej woli zapłacił za niego hr. Marianowi Czapskiemu (Верность и в жизни и в смерти, „Обзор”, 6 II 2014).

44 LVIA, Ф. 525 (Управление Земледелия и Государственных Имуществ в Виленской и Ковенской губерни), оп. 18, д. 102, л. 980.

45 Ibidem.

46 Dopiero po czterech latach hr. Edward Czapski otrzymał pieniądze przyznane mu przez sąd wileński. Mówi o tym list ministra Dóbr Państwowych do kowieńskiego zarządu Ministerstwa Dóbr Państwowych z 21 stycznia 1878 r., aby zgodnie z wyrokiem sądu sumy wykupne w wysokości 27700 i 18192 rubli przekazać hr. Edwardowi Czapskiemu (ibidem, л. 981).

47 „Ignacogród, dwór nad Niewiażą, powiat kowieński, okręg policyjny kiejdański, parafia opitołocka, o 2 mile od Kiejdan, o 61 wiorst od Kowna, 17 mieszkańców, młyn wodny (1859). Dawna własność Zawiszów, potem do roku 1863 Gieysztora. Śród ogrodu murowana biblioteka zawierała 5000 druków, przeważnie polskich lub o Polsce. Obszar folwarku włók 30 w gruntach bardzo dobrych" (J. K. G., Ignacogród, [w:] Słownik..., t. III, Warszawa 1882, s. 244).

48 Kauno Apskrities Archyvas, Kaunas [dalej: КАA] Ф. И-78 (Ковенская палата Уголовного и гражданского суда), оп. 1, д. 1440 (О вводе во владение тайного советника Аркадия Стольпина имением Игнацегороды, 7-12 марта 1874 г.). 
w dniu 12 marca 1874 roku $^{49}$. Walenty Bieługin, pełnomocnik generała upoważniony do załatwiania wszelkich formalności związanych obydwoma majątkami, działał bardzo sprawnie, gdyż jednocześnie z dokumentacją dotyczącą Ignacegrodu złożył w sądzie identyczną w sprawie Kałnoberży. Okazało się bowiem, że po kupnie tego majątku, częściowo wygranego w karty od generała Sergiusza Kuszeliewa, ojciec Piotra Stołypina zaniedbał ostatnich formalności, czyli uzyskania aktu własności wydanego przez sąd. Ten akt sądowy przyznający generałowi Arkadiuszowi Stołypinowi pełne prawa własności do majątku Kałnoberże nosi datę 13 marca 1874 roku $^{50}$.

Nie ulega wątpliwości, że generałowi Arkadiuszowi Stołypinowi bardzo zależało na kupnie Ignacegrodów już choćby tylko z jednego powodu - sąsiadowały one z Kałnoberżami i po ich zakupie ogólna powierzchnia posiadłości generała w powiecie kowieńskim, w dodatku zgrupowana w jednym miejscu, wzrosła do 1325,25 dziesięciny i 1848 sążni kwadratowych. Prawdopodobnie tylko dlatego wziął udział w licytacji, wygrał ją i ostatecznie zapłacił za Ignacegrody 22 096,5 rubli, czyli za majątek o powierzchni 489 dz. 1848 sążni zapłacił dwukrotnie więcej niż za Kałnoberże liczące 836,25 dziesięcin. W przeliczeniu na jedną dziesięcinę oznaczało to, że dziesięcina ziemi w Ignacegrodach kosztowała generała 45 rubli, a w Kałnoberżach 12 rubli. Generał osobiście nie gospodarował w żadnym z majątków, choć, jak pisze Borys Fiedorow, „do śmierci żony generała, Natalii Stołypin, w 1889 roku, rodzice każde lato spędzali

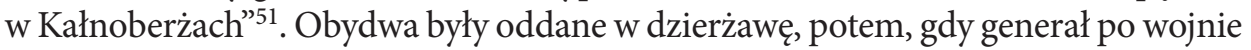
tureckiej nie wrócił już do Wilna i na Kowieńszczyznę, Kałnoberże otrzymał Piotr Stołypin, a Ignacegrody Maria - jedyna siostra Piotra Stołypina ${ }^{52}$.

W skali całego powiatu kowieńskiego Kałnoberże nie były też małą posiadłością. W $1880 \mathrm{r}$. w powiecie kowieńskim znajdowało się 7 majątków o powierzchni do 1000 dziesięcin ${ }^{53}$. Dla porównania: w powiecie wiłkomirskim było takich majątków 10, w nowoaleksandrowskim (jezioroskim) - 7, poniewieskim - 17, szawel-

49 Ibidem, л. 8.

50 КАА, Ф. И-78 (Ковенская палата Уголовного и гражданского суда), оп. 1, д. 1453 (О вводе во владение тайного советника Аркадия Столыпина имением Калноберже, 13 марта 1874 г.), л. 9.

51 Б. Г. Федоров, ор. cit., Т. 1, с. 117.

52 Aleksander, młodszy brat Piotra Stołypina, miał także nieokreślonej wielkości „daczę” Biecze w guberni kowieńskiej, położoną w odległości 60 wiorst (64 kilometrów) od Kałnoberży. Latem 1911 r. Piotr Stołypin wraz ze swoją rodziną odwiedził brata w tej miejscowości. Wspominała Maria Bock: „Wujek Aleksander Arkadiewicz Stołypin przebywał tego lata w swoim majątku Biecze, leżącym w odległości 60 wiorst od Kałnoberży. Tato zdecydował się na odwiedziny. Pojechaliśmy z nim jego wagonem i spędziliśmy z wujostwem cały dzień. Ten cudowny letni dzień okazał się ostatnim spotkaniem obydwu braci” (М. Вок, op. cit., c. 175). O dzieciństwie i wakacjach spędzonych w majątku Biecze przez Arkadiusza Stołypina (1894-1990), jedynego syna Aleksandra, krótko pisze także autor wprowadzenia do jego dziennika (А. А. Столыпин, Записки драгунского офицера. Дневники 1919-1920 годов, [w:] И. П. Романовский, Письма 1917-1920 годов, Москва-Брюссель 2011, с. 3.

53 Statystyka wielkości obszarów wszystkich gospodarstw z powiatu kowieńskiego niewchodzących w skład nadziałów chłopskich wyglądała następująco: do 25 dz. -1020 gospodarstw; do 50 dz. - 365; do 100 dz. - 169; do 200 dz. - 106; do 350 dz. - 58; do 500 dz. - 30; do 700 dz. - 10; do 1000 dz. 7; do 1500 dz. - 4; do 2000 dz. -5; do 2500 dz. - 2; do 3000 dz. - 1, powyżej 3000 dz. były to tylko majątki hr. Benedykta Tyszkiewicza (Памятная книжка Ковенской губерни на 1880 год, Ковна 1879, с. 286). 
skim - 14, telszewskim - 9, rosieńskim - $12^{54}$. Można więc śmiało powiedzieć, że Piotr Stołypin, któremu ojciec oddał Kałnoberże w 1889 r. po objęciu stanowiska kowieńskiego powiatowego marszałka szlachty ${ }^{55}$, był jednym z większych właścicieli ziemskich w powiecie i jednym z kilkudziesięciu większych właścicieli ziemskich w guberni kowieńskiej.

The estate won in a game of cards: how the Lithuanian estate of Kałnoberże fell into the hands of the Stolypin family after the January Uprising

In spite of Russian historiography's post-1990 intensive interest in the biography of Pyotr Stolypin, and a large number of books and articles covering this subject, still no extensive research was conducted regarding the "Kovno period" of Stolypin's administrative career, i.e. in the years 1889-1902. In an excerpt from his monograph on this subject, the author recalls the story of the Kałnoberże estate, the Stolypin family' favourite. Not much can be said on how the property fell into the hands of the Stolypins. In her memoirs about her father, Maria Bock, eldest daughter of Pyotr Stolypin, wrote that her grandfather, General Arkadiy Stolypin, had won Kałnoberże from his relative, General Sergey Kushyelev, as a bet in a game of cards. This statement is repeated by almost all contemporary Russian historians covering the subject, while it is belied by the accounts of Polish landowners from the Kovno Governorate, who claim in their memoirs that Kałnoberże had been "granted" to General Stolypin for his Russification efforts in Lithuania after the 1863 Uprising. However, it appears that their memoirs, in spite of being seemingly reliable, do not correspond to the freshly unveiled historical facts. The author compares Maria Bock's memoirs with the accounts of Mieczysław Jałowiecki, Aleksander Meysztowicz and Walerian Meysztowicz, and then with the archival materials that he recently discovered. The examination of the latter partially confirms the hypothesis of Kałnoberże being won by Pyotr Stolypin's father in a game of cards, and allows the depiction of the whole acquisition process of the estate by the Stolypin family.

Translated by Jakub Perliński

\section{Имение, выигранное в карты - как после Январского восстания литовское Калноберже попало в руки семьи Столыпиных}

В российской историографии, обращающейся к жизни и деятельностью Петра Аркадьевича Столыпина, несмотря на большое количество книг и научных статьей, до сих пор нет научной о так называемом «ковенском периоде» его жизни и карьеры в 1899-1902 гг. Автор настоящей статьи, завершающий научную монографию о П.А.Столыпине, сконцентрировал внимание на истории имения Калноберже - любимой усадьбе семьи П. А. Столыпина. До сих пор было очень мало известно о том, как это имение попало в руки семьи Столыпиных. Мария Бок, первая дочь П.А.Столыпина написала в своих «Воспоминаниях об отце - что ее дедушка генерал Аркадий Д. Столыпин выиграл Калноберже в карты у

\section{Ibidem.}

55 Po powstaniu styczniowym na Ziemiach Zabranych zlikwidowano samorząd szlachecki i zasadę wybierania marszałków szlachty. W miejsce wybieranych marszałków szlachty mianowano предводители дворянства. We wspomnieniach polskich ziemian kresowych często używano spolszczonego „priedwoditiel”, w celu odróżnienia go od „marszałka szlachty”. Przy tym ostatnim określeniu zazwyczaj dodawano „ostatni z wyboru”. 
своего родственника генерала Сергея Е. Кушелева. Эту информацию повторяют почти все российские историки, которые занимаются П.А.Столыпином, но этому факту мы не находим подтверждения в воспоминаниях польских помещиков, которые соседствовали со Столыпиными в Ковенской губернии на рубеже XIX - XX вв. Они утверждали, что генерал А.Д.Столыпин получил это имение как награду за свою «русификаторскую» деятельность в Литве после Январского восстания 1863 года. Автор сопоставляет информацию Марии Бок и воспоминания помещиков Мечислава Яловецкого, Александра и Валериана Мейштовичей с новыми, ранее неизвестными архивными материалами, которые были им обнаружены в литовских архивах. В итоге, автор получил частичное подтверждение информации о выигрыше А.Д.Столыпиным имения Калноберже в карты и прослеживает, таким образом, весь процесс приобретения Столыпиными этого имения во второй половине XIX века.

Перевод Агнешка Поспишьль

\section{Bibliografia}

Źródła archiwalne:

Kauno Apskrities Archyvas, Kaunas [dalej: KAA], Ф. И-78 (Ковенская палата Уголовного и гражданского суда), оп. 1, д. 1453 (О вводе во владение тайного советника Аркадия Столыпина имением Калноберже, 13 марта 1874 г.).

КАА, Ф. И-78 (Ковенская палата Уголовного и гражданского суда), оп. 1, д. 1440 (О вводе во владение тайного советника Аркадия Столыпина имением Игнацегороды, 7-12 марта 1874 2.).

Lietuvos Valstybès Istorijos Archyvas, Vilnius [dalej: LVIA], Ф. 525 (Управление Земледелия и Государственных Имуществ в Виленской и Ковенской губерни), оп. 18, д. 102 (Дело о передаче в казну конфискованного у графа Чапского имения Калноберже, Ковенского уезда и о передаче его в аренду. Имеется инвентарное описание имения 1863 г., л. 1-1240).

LVIA, Ф. 378 (Канцелярия виленского, ковенского и гродненского генерал-губернатора), оп. 216, д. 397.

Meysztowicz A., Kowieńskie Towarzystwo Rolnicze w latach 1900-1904, Zakład Narodowy im. Ossolińskich we Wrocławiu, sygn. 15555.

Źródła drukowane:

Липинский И. М., Некоторые данные для изучения ковенской губерни в статистическом отношении, [w:] Памятная книжка ковенской губернии на 1889 год, Ковна 1888.

Памятная книжка Ковенской губерни на 1880 год, Ковна 1879.

Полное Собрание Законов Российской Империи, Собрание второе, T. XL, 1865, № 41957; T. XLII, № 42328 a.

Pamiętniki i wspomnienia drukowane:

Бок М., П. А. Стольпин. Воспоминания о моем отие, [w:] Российские судьбы. Жизнеописания, факты и гипотезы, портреты и документы в 30 книгах. Издатель К. В. Крепов, Москва 1998.

Jałowiecki M., Na skraju Imperium, Warszawa 2000.

Meysztowicz A., Wspomnienia i refleksje o Stołypinie, „Kurier Wileński” z 20 IX 1911.

Meysztowicz W., Poszło z dymem, Gawędy o czasach i ludziach, Warszawa 1989.

Skirmunt, K. Moje wspomnienia 1866-1945. Wstęp i opracowanie Ewa Orloff, Andrzej Pasternak, Rzeszów 1977. 
Stołypin A., Cesarstwo i wygnanie. Przed i po roku 1917. Pamiętniki. Przy współpracy Dymitra Stołypina, Warszawa 1998.

Столыпин А. А., Записки драгунского офицера. Дневники 1919-1920 годов, [w:] И. П. Романовский, Письма 1917-1920 годов, Москва-Брюссель 2011.

Słowniki i encyklopedie:

Петр Аркадьевич Стольпин, Энииклопедия, Москва 2011.

Słownik Geograficzny Królestwa Polskiego i innych krajów słowiańskich, t. III, Warszawa 1882, t. IV, Warszawa 1883.

Monografie i artykułu naukowe:

Bazylow L., Ostatnie lata Rosji carskiej. Rządy Stołypina, Warszawa 1972.

Бородин А. П., Стольпин. Реформы во имя России, Москва 2004.

Черепица В. Н., П. А. Столыпин (1862-1911) - гродненский губернатор и великий реборматор России, [w:] История Гродненщины ХІХ столетия в событиях и тииах (исследования, документы, комментари), Гродно 2003, с. 6-47.

Федоров Б. Г., Петр Стольпин: „Я верю в Россию”. Биография П. А. Стольпина, Т. I, С. Петербург 2002.

Jurkowski R., „I Left Quite a Few Friends There”. Piotr Stolypin and Polish Landowners from the Taken Lands between 1899 and 1911, [in:] Russia: of the Tsars, of the Bolsheviks, of the new times, Edited by Jan Malicki, Centre for East European Studies University of Warsaw, Warsaw 2012, p. 43-44.

Jurkowski R., Tsarist Russia - Bolshevik Russia - contemporary Russia. Special session with the ceremony of conferring the title of doctor honoris causa of the University of Warsaw to profesor Richard Pipes. Warsaw 29-30 June 2010, „Echa Przeszłości” („Echoes of the Past”), R. XII, 2010, p. 211-217.

Jurkowski R., Ziemiaństwo polskie Kresów Pótnocno-Wschodnich 1864-1904, Działalność społeczno-gospodarcza, Warszawa 2001.

Nieścioruk J., Piotr Stołypin. Życie i działalność polityczna, Lublin 2007.

Панютич В. П., Социально-экономическое развитие белоруской деревни в 1861-1900 г2., Минск 1990.

Сидоровин Г. П., Петр Аркадьевич Стольпин. Жизнь за отечество, Москва 2007.

Верность и в жизни и в смерти, „Обзор”, 6 II 2014.

Зырянов П. Н., Петр Стольпин. Политический портрет, Москва 1992.

Roman Jurkowski - historyk, profesor nadzwyczajny w Instytucie Historii i Stosunków Międzynarodowych Uniwersytetu Warmińsko-Mazurskiego w Olsztynie. Zajmuje się dziejami polskich elit ziemiańskich z Ziem Zabranych, historią polskiej myśli politycznej na tych obszarach w II połowie XIX i na początku XX wieku. Autor trzech monografii: Ziemiaństwo polskie Kresów Północno-Wschodnich 1864-1904. Działalność społeczno-gospodarcza, Warszawa 2001; Sukcesy i porażki. Ziemiaństwo polskie Ziem Zabranych w wyborach do Dumy państwowej i Rady Państwa 1906-1013, Olsztyn 2009; Successes and failures. Polish landowners from the Nine Western provinces in the elections to the Russian State Duma and State Council in the years 1906-1913, Olsztyn 2013 oraz wydawcą zbioru dokumentów Zanim przyszła "Pożoga”. Dokumenty i materiały do działalności polityczno-społecznej Polaków na Podolu w latach 1905-1910. Wstęp, wybór i opracowanie Roman Jurkowski, Olsztyn 2011. Jest autorem ponad 120 artykułów naukowych. 